\title{
Dietary sodium modulates nephropathy in Nedd4-2-deficient mice
}

\author{
Jantina A. Manning ${ }^{1} \cdot$ Sonia S. Shah ${ }^{1} \cdot$ Tanya L. Henshall $^{1} \cdot$ Andrej Nikolic $^{1} \cdot$ John Finnie $^{2,3} \cdot$ Sharad Kumar $^{1,2}$
}

Received: 24 September 2019 / Revised: 20 November 2019 / Accepted: 21 November 2019 / Published online: 4 December 2019

(c) The Author(s) 2019. This article is published with open access

\begin{abstract}
Salt homeostasis is maintained by tight control of $\mathrm{Na}^{+}$filtration and reabsorption. In the distal part of the nephron the ubiquitin protein ligase Nedd4-2 regulates membrane abundance and thus activity of the epithelial $\mathrm{Na}^{+}$channel (ENaC), which is rate-limiting for $\mathrm{Na}^{+}$reabsorption. Nedd4-2 deficiency in mouse results in elevated ENaC and nephropathy, however the contribution of dietary salt to this has not been characterized. In this study we show that high dietary $\mathrm{Na}^{+}$ exacerbated kidney injury in Nedd4-2-deficient mice, significantly perturbing normal postnatal nephrogenesis and resulting in multifocal areas of renal dysplasia, increased markers of kidney injury and a decline in renal function. In control mice, high dietary $\mathrm{Na}^{+}$resulted in reduced levels of ENaC. However, Nedd4-2-deficient kidneys maintained elevated $\mathrm{ENaC}$ even after high dietary $\mathrm{Na}^{+}$, suggesting that the inability to efficiently downregulate $\mathrm{ENaC}$ is responsible for the salt-sensitivity of disease. Importantly, low dietary $\mathrm{Na}^{+}$significantly ameliorated nephropathy in Nedd4-2-deficient mice. Our results demonstrate that due to dysregulation of ENaC, kidney injury in Nedd4-2-deficient mice is sensitive to dietary $\mathrm{Na}^{+}$, which may have implications in the management of disease in patients with kidney disease.
\end{abstract}

\section{Introduction}

Early stages of chronic kidney disease (CKD), such as histological changes to the glomerular, tubular, interstitial and/or vascular compartments result in the destruction of the renal parenchyma and functional nephron loss [1], as well as fibrosis and inflammation [2]. Early onset CKD can be attributed to monogenic mutations in one of $\geq 200$ genes [3]. Recently, Nedd4-2 has been identified as a novel gene

Edited by G. Melino

Supplementary information The online version of this article (https:// doi.org/10.1038/s41418-019-0468-5) contains supplementary material, which is available to authorized users.

Jantina A. Manning

Jantina.manning@unisa.edu.au

$\bowtie$ Sharad Kumar

sharad.kumar@unisa.edu.au

1 Centre for Cancer Biology, University of South Australia and SA Pathology, Adelaide, SA 5001, Australia

2 Faculty of Medicine, University of Adelaide, Adelaide, SA 5005, Australia

3 SA Pathology, Frome Road, Adelaide, SA 5000, Australia that protects against early onset $\mathrm{CKD}$, with mice deficient for Nedd4-2 displaying many features of early stage CKD pathology [4]. In addition, decreased expression of NEDD4L (human Nedd4-2) has been correlated with early stage human diabetic nephropathy [5].

Despite recent advances in identifying genetic causes of nephropathy, the mechanisms that connect underlying genetic defects with environmental factors associated with the progression of kidney disease, such as high dietary salt intake are poorly understood [6]. The regulation of $\mathrm{Na}^{+}$ homeostasis in response to dietary salt requires complex coordination between renal tubular filtration and reabsorption [7]. Reabsorption of $\mathrm{Na}^{+}$is mediated by multiple channels and transporters along the length of the nephron including the epithelial $\mathrm{Na}^{+}$channel $(\mathrm{ENaC})$ and the $\mathrm{Na}^{+} \mathrm{Cl}^{-}$cotransporter (NCC) [8]. In the late distal convoluted tubule, the connecting tubule and the collecting duct, $\mathrm{ENaC}$ is the rate-limiting factor in $\mathrm{Na}^{+}$reabsorption.

$\mathrm{ENaC}$ is a heterotrimeric channel composed of three subunits; $\alpha, \beta$, and $\gamma$, which undergoes complex processing and activation [9]. Short inhibitory peptides in the $\alpha$ and $\gamma$ subunits are cleaved by proteases to release the active channel [10-12], and N-linked glycan remodeling on all subunits is required for folding, expression' and function [10]. Many factors contribute to the regulation of $\mathrm{ENaC}$, including inhibition by extracellular $\mathrm{Na}^{+}$[13]. In mice, 
dietary salt has been reported to modulate $\mathrm{ENaC}$ subunit expression [14-16], as high dietary $\mathrm{Na}^{+}$decreases cell surface abundance of $\mathrm{ENaC}$ whereas low dietary $\mathrm{Na}^{+}$ increases cell surface abundance [16]. Similarly, in saltresistant Sprague-Dawley rats, increased dietary $\mathrm{Na}^{+}$reduces $\mathrm{ENaC}$, resulting in a decrease in $\mathrm{ENaC}$-driven reabsorption of $\mathrm{Na}^{+}[14,17]$. Conversely, low dietary $\mathrm{Na}^{+}$ activates ENaC [18]. However, in Dahl salt-sensitive rats, increased dietary $\mathrm{Na}^{+}$leads to the hyperactivation of $\mathrm{ENaC}$ $[17,19]$. Further support for the role of $\mathrm{ENaC}$ in modulating $\mathrm{Na}^{+}$reabsorption from dietary salt intake is demonstrated in patients with Liddle syndrome [20] and related mouse models [4, 21], where elevated ENaC function is associated with salt-sensitive hypertension.

The amount of ENaC on the membrane is a primary determinant of its function, with ubiquitination a major pathway controlling the retrieval of this channel from the cell surface [8]. Nedd4-2, a HECT domain containing ubiquitin ligase, binds to PY motifs within the C-termini of all three $\mathrm{ENaC}$ subunits to facilitate removal from the membrane [22-24]. Deletion or mutations in PY motifs are known to be associated with increased $\mathrm{ENaC}$ and hypertension in Liddle patients [20]. Increased ENaC levels and activity are also seen in Nedd4-2-deficient mice, highlighting the relevance of this regulation in vivo [25]. Previously, we demonstrated that elevated ENaC contributes to the development of kidney disease in Nedd4-2-deficient mice, as treatment with the ENaC inhibitor amiloride ameliorated the observed nephropathy $[4,26]$.

Here, we show for the first time that improper regulation of $\mathrm{ENaC}$ in the absence of Nedd4-2 in mice is exacerbated under conditions of high dietary $\mathrm{Na}^{+}$, resulting in nephropathy that is strikingly sensitive to dietary $\mathrm{Na}^{+}$. Importantly, a low $\mathrm{Na}^{+}$diet dramatically reduces kidney damage. As the function of Nedd4-2 in regulating $\mathrm{Na}^{+}$homeostasis is highly conserved in mouse and man, our findings are potentially important for the management and treatment of nephropathy in human patients.

\section{Methods}

\section{Study approval and mouse lines}

All animal studies were approved by the institutional ethics and biosafety committees of SA Pathology/CALHN/University of South Australia and were carried out according to the National Health and Medical Research Council of Australia guidelines. Nedd4-2 $2^{-/}$mice and kidney-specific Nedd4-2-deficient mice (Nedd4-2 ${ }^{\text {Ksp } 1.3}$ ) were generated in our laboratory previously [4, 27] and bred at the SA Pathology animal care facility or UniSA Core Animal
Facility (Adelaide, Australia) under specific pathogen free conditions.

\section{Variable salt feeding and sample collection}

Nedd4-2 $2^{+/-}$females were time mated with $N e d d 4-2^{+/-}$ males. Upon the observation of a vaginal plug, diet was changed to low sodium chow $\left(0.05 \% \mathrm{Na}^{+}\right)$, standard sodium chow $\left(0.2 \% \mathrm{Na}^{+}\right)$, or high sodium chow $\left(3.1 \% \mathrm{Na}^{+}\right)$ (Specialty Feeds, WA, Australia). Sample sizes were determined according to $G$ Power calculations and approved by the Institutional Ethics Committee, and randomly assigned to treatment groups, non-blinded due to the nature of disease progression. For embryonic studies, pregnant Nedd4-2 $2^{+/-}$mothers (five for each diet condition) were humanely killed by cervical dislocation and embryos taken at embryonic day (E) 18.5. Embryos were removed from the yolk sac, decapitated, and tail tip was taken for genotyping. Kidneys were dissected, and one placed into Histochoice reagent (ProSciTech, Kirwan, QLD, Australia) for the histological analysis of paraffin embedded or frozen samples. For paraffin samples, kidneys were transferred to $70 \%$ ethanol and then embedded in paraffin. Kidneys for frozen sectioning were soaked in 30\% sucrose overnight before being embedded in OCT (ProSciTech, Kirwan, QLD, Australia). The remaining kidney was snap frozen in liquid nitrogen for immunoblot and mRNA analysis. For the Nedd4-2 $2^{K s p 1.3}$ strain, low and standard $\mathrm{Na}^{+}$diet was continued during pregnancy and lactation, and in solid chow of male and female pups until they were humanely killed for analysis at 40 days. High- $\mathrm{Na}^{+}$diet was continued during pregnancy and lactation until the pups were humanely killed for analysis at 20 days. At the time of collection, mice were anaesthetized, blood collected by cardiac puncture, and organs dissected after cervical dislocation. The capsule was removed, and one kidney was snap frozen in liquid nitrogen, the other was cut in half in the coronal plane and immersion fixed in Histochoice for $48 \mathrm{~h}$ at $4{ }^{\circ} \mathrm{C}$. One half of the kidney was paraffin embedded and the other OCT embedded as above. Nine mice of each genotype, for each diet condition were analyzed.

\section{Histological analysis}

Sections $(5 \mu \mathrm{m})$ were cut using a paraffin microtome, deparaffinized with xylene, and dehydrated through a graded series of ethanol. Slides were stained with hematoxylin-eosin using standard protocols. To evaluate collagen deposition using picrosirius red, slides were stained for $1 \mathrm{~h}$ in saturated picric acid with $0.1 \%$ Direct Red 80 (Sigma-Aldrich), then washed in acidified water for $2 \mathrm{~min}$. Digital images were acquired by using a NanoZoomer (Hamamatsu). 


\section{Immunostaining}

Immunostaining for KIM-1 and all $\mathrm{ENaC}$ subunits were carried out on frozen sections $(14 \mu \mathrm{m})$. Tissue sections were blocked with $10 \%$ goat serum and incubated with primary antibodies: rat anti-KIM-1 (cat. \# MAB1817, R\&D systems); rabbit anti- $\alpha-\mathrm{ENaC}$ and rabbit anti- $\gamma-\mathrm{ENaC}$ [28]; rabbit anti- $\beta$-ENaC [27], or rabbit anti-NCC (cat. No. ab3553; Abcam). Sections were then incubated with the corresponding fluorescently tagged secondary antibody (AlexaFluor-488, Thermo Fisher Scientific), counterstained with DAPI, and mounted in Prolong Gold Antifade reagent (Invitrogen). Stained samples were imaged using an LSM 800 confocal microscope using Zen 2011 (Black Edition) version 8.1.5.484 (Carl Zeiss Microscopy, Jena, Germany). Image analysis was conducted using Adobe image suite software.

\section{Immunoblotting}

Half of each kidney was lysed in ice-cold extraction buffer at pH $7.5(50 \mathrm{mM}$ Tris-HCl pH 7.5, $1 \mathrm{mM}$ EDTA, $1 \mathrm{mM}$ EGTA, $0.27 \mathrm{M}$ sucrose, $0.1 \% \quad \beta$-mercaptoethanol, and HALT protease and phosphatase inhibitor cocktail [Thermo Fisher Scientific]). Tissue was homogenized, frozen in liquid nitrogen, immediately thawed, and incubated at $4{ }^{\circ} \mathrm{C}$ on a Nutator for $30 \mathrm{~min}$ and centrifuged at 13,000 rpm for $5 \mathrm{~min}$. Supernatant protein $(25 \mu \mathrm{g})$ was combined with protein load buffer (100 mM Tris-HCl pH 6.8, $200 \mathrm{mM}$ DTT, 4\% SDS, $0.2 \%$ bromophenol blue, and $20 \%$ glycerol), heated at $37{ }^{\circ} \mathrm{C}$ for $30 \mathrm{~min}$, loaded onto 4-20\% precast SDS-PAGE gels (Bio-Rad), and transferred to PVDF membrane using the Trans-blot Turbo instrument (Bio-Rad). Membranes were blocked with 5\% skim milk in TBS-T (Tris-buffered saline/ $0.05 \%$ Tween 20 ) and primary antibodies added; anti- $\alpha, \beta$ or $\gamma$-ENaC, anti-NCC (as described above), anti-Nedd4-2 [4], and mouse anti- $\beta$-actin (clone AC15; Sigma-Aldrich). For ENaC, NCC, and Nedd4-2 antibodies, HRP secondary antibodies (Millipore) were added and developed with West Femto (Thermo Scientific). $\beta$-actin was developed using Cy5 secondary (GE Healthcare). Images were acquired on a ChemiDoc Touch Imager (Bio-Rad). Quantitation was conducted using Image Lab Software (Bio-Rad), with each band normalised to $\beta$-actin and presented as fold change from control standard $\mathrm{Na}^{+}$condition.

\section{Real-time quantitative PCR}

Total RNA was isolated from half of each kidney using TRIzol Reagent (Life Technologies) and RNA was reversetranscribed with a high capacity cDNA reverse transcription kit (Applied Biosciences). qRT-PCR was performed and analyzed as described [29], where all data are normalized to
TBP (TATA-box binding protein) levels. Primer sequences are detailed below:

\begin{tabular}{|c|c|}
\hline Gene & Primer sequence $\left(5^{\prime}-3^{\prime}\right)$ \\
\hline \multirow[t]{2}{*}{$\begin{array}{l}\text { Collagen-1 } \\
\text { (Collal) }\end{array}$} & $\begin{array}{l}\text { F: CGGAGAAGAAGGAAAAC } \\
\text { GAGGAG }\end{array}$ \\
\hline & $\begin{array}{l}\text { R: CACCATCAGCACCAGG } \\
\text { GAAAC }\end{array}$ \\
\hline \multirow[t]{2}{*}{ Vimentin (Vim) } & F: CGGCTGCGAGAGAAATTGC \\
\hline & $\begin{array}{l}\text { R: CCACTTTCCGTTCAAGGT } \\
\text { CAAG }\end{array}$ \\
\hline \multirow{2}{*}{$\begin{array}{l}\text { Kidney injury } \\
\text { molecule } 1(K I M-1)\end{array}$} & F: TGGTTGCCTTCCGTGTCTCT \\
\hline & R: TCAGCTCGGGAATGCACAA \\
\hline \multirow[t]{2}{*}{$\begin{array}{l}\text { TATA-box binding } \\
\text { protein }(T B P)\end{array}$} & $\begin{array}{l}\text { F: CAAACCCAGAATTGTTCTC } \\
\text { CTT }\end{array}$ \\
\hline & $\begin{array}{l}\text { R: ATGTGGTCTTCCTGAATCC } \\
\text { CT }\end{array}$ \\
\hline
\end{tabular}

\section{Electrolytes and aldosterone}

Electrolytes, aldosterone, and other parameters of kidney function in blood were measured at SA Pathology. Plasma $\mathrm{Na}^{+}, \mathrm{K}^{+}, \mathrm{Cl}^{-}, \mathrm{Ca}^{2+}$, and creatinine were measured using an Advia 2400 chemistry system (Siemens), and urine osmolality with an Advanced 3320 osmometer (Advanced Instruments). Plasma aldosterone levels were measured using a Liaison Aldosterone Kit and a Chemiluminescent Analyzer (Diasorin, Saluggia, Italy).

\section{Statistical analysis of data}

Statistical analysis was performed using GraphPad Prism software (v6.0). A Mann-Whitney test for nonparametric data was used to assess changes in blood parameters. All other data were analysed using unpaired 2-tailed Student's $t$ test. A $P$ value of $\leq 0.05$ was considered significant. All values are presented as mean \pm SEM.

\section{Results}

\section{High dietary $\mathrm{Na}^{+}$exacerbates kidney injury}

Mice deficient for Nedd4-2 progressively develop kidney disease accompanied by higher expression of $\mathrm{ENaC}$ and NCC, resulting in increased $\mathrm{Na}^{+}$reabsorption [4]. To investigate whether high dietary $\mathrm{Na}^{+}$would induce earlier onset of disease, or an exacerbated disease 
Fig. 1 High dietary $\mathrm{Na}^{+}$ exacerbates kidney pathology in Nedd4-2 ${ }^{K s p 1.3}$ mice. a Outline of salt-feeding experiments. b Representative H\&E images show increase in kidney injury after high- $\mathrm{Na}^{+}$diet in P20 kidneys. Red lines denote areas of damage. Scale bar: $1 \mathrm{~mm}$, inset $100 \mu \mathrm{m}$. c Picrosirius red staining shows fibrosis after the high-Na ${ }^{+}$diet in Nedd4-2 $2^{K s p l .3}$ kidneys. Scale bar: $100 \mu \mathrm{m}$. d KIM-1 staining shows small regions of injury in Nedd4$2^{\text {Ksp } 1.3}$ kidneys under standard$\mathrm{Na}^{+}$diet, and extensive regions after high- $\mathrm{Na}^{+}$diet. Scale bar: $250 \mu \mathrm{m}$. e qPCR for markers of kidney injury collagen

I (Colla1), vimentin and KIM-I show the significant increases in Nedd4-2 $2^{\text {Ksp I.3 }}$ kidneys after the high- $\mathrm{Na}^{+}$diet $(n=6-7$ mice per genotype). Data are shown as fold change from control on standard (Std.) diet, mean \pm SEM with significance calculated by a Student's $t$ test (two tailed). f Serum levels of $\mathrm{Na}^{+}$remain unchanged, however, creatinine and urea are increased in Nedd4-2 ${ }^{K s p l .3}$ mice after the high- $\mathrm{Na}^{+}$diet. Data are presented as one point per mouse, mean \pm SEM with significance calculated by a Mann-Whitney test. $* P<0.05$, $* * P<0.01, * P<0.005$, $* * P<0.001$. a

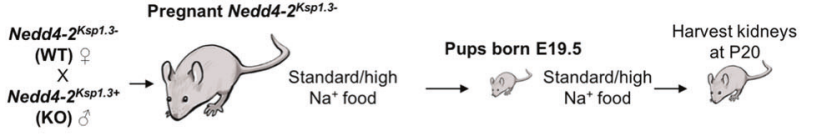

b
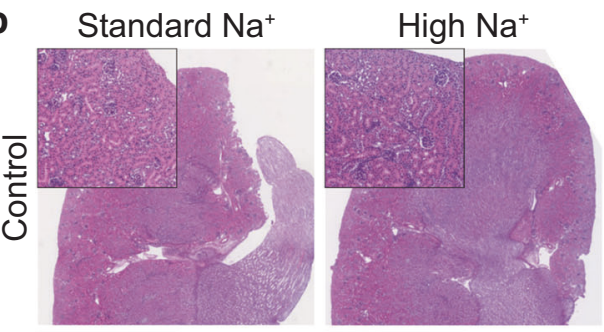

C Standard $\mathrm{Na}^{+}$
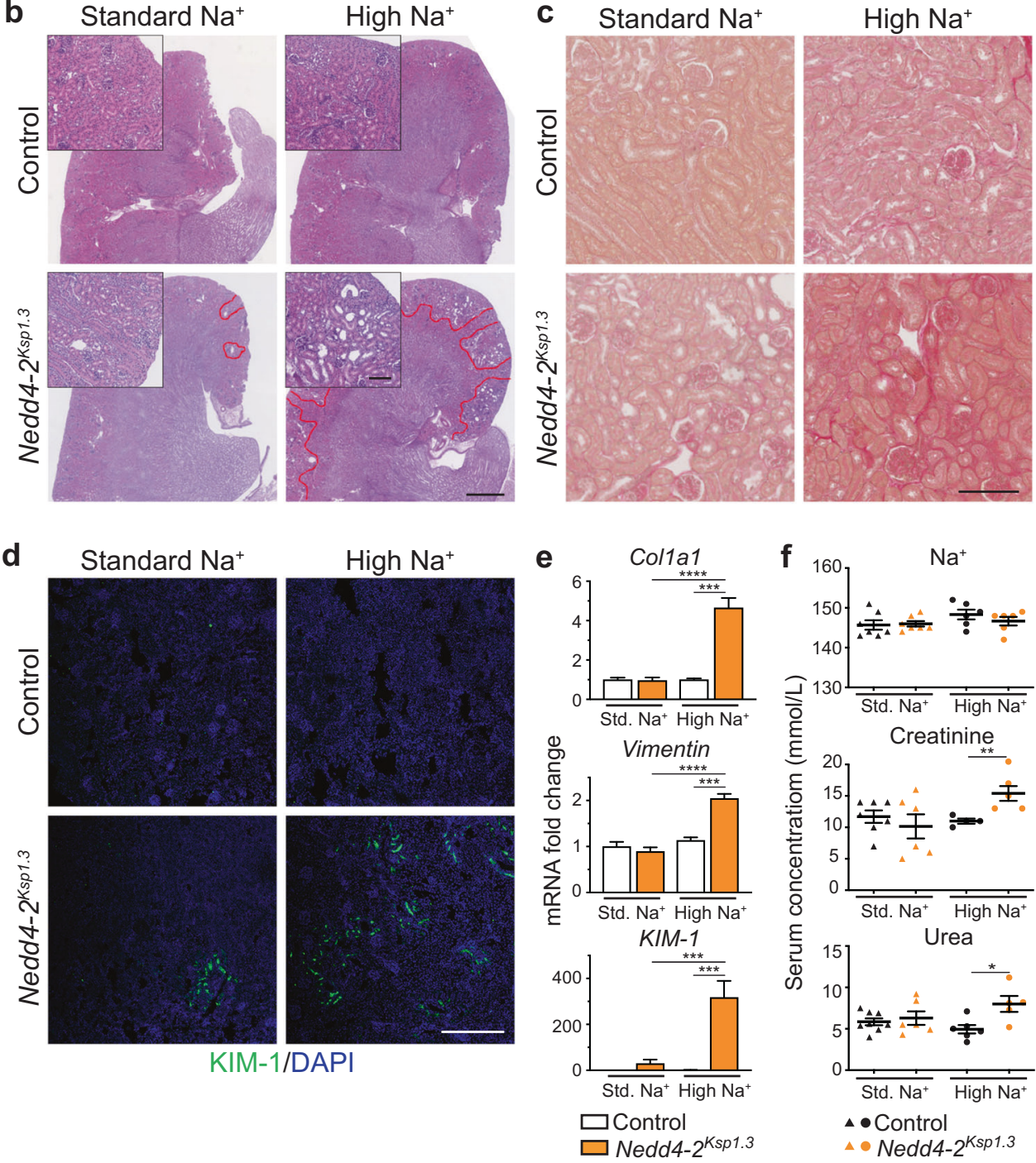

phenotype, we utilized renal tubule specific Nedd4-2deficient mice, Nedd4-2 ${ }^{K s p 1.3}$. Pregnant mice were fed a standard $\mathrm{Na}^{+}(0.2 \%)$ or high- $\mathrm{Na}^{+}(3.1 \%)$ diet for the duration of pregnancy/lactation and continued in the solid food of pups (Fig. 1a). Initially, we found that this diet caused lethality of the first high $\mathrm{Na}^{+}$fed Nedd4$2^{\text {Ksp } 1.3}$ mouse at P38. Hence, subsequent mice on high$\mathrm{Na}^{+}$diet were analyzed at postnatal day (P) 20, since we have previously shown the initiation of pathology at this age [4]. On a standard $\mathrm{Na}^{+}$diet, kidneys of Nedd4 $-2^{K s p 1.3}$ mice were similar to control mice, with only minor pathology comprised of a few small, focal areas of dysplasia in the cortex (Fig. 1b). After a high- $\mathrm{Na}^{+}$diet, there were numerous multifocal areas of renal dysplasia, which were characterized by cortical immaturity in the form of small, hypercellular glomeruli with inapparent capillaries, immature tubules (with often dilated lumina, which sometimes contained desquamated, degenerate epithelial lining debris), and persistent interstitial mesenchyme (Fig. 1b and Supplementary Fig. 1). Many collecting ducts were also immature and sometimes disorganized. Picrosirius red staining revealed a small increase in fibrosis in Nedd4-2-deficient kidneys (Fig. 1c) and KIM-1 immunohistochemistry demonstrated more extensive regions of renal damage (Fig. 1d). Markers of renal injury; collagen, vimentin, and KIM-I were all significantly increased in Nedd $4-2^{K s p 1.3}$ kidneys after 20 days of the high- $\mathrm{Na}^{+}$diet (Fig. 1e). 
Table 1 P20 serum analysis of Control and Nedd4-2 $2^{K s p 1.3}$ mice.

\begin{tabular}{|c|c|c|c|c|}
\hline & \multicolumn{2}{|l|}{ Standard $\mathrm{Na}^{+}$} & \multicolumn{2}{|l|}{ High $\mathrm{Na}^{+}$} \\
\hline & Control $(n=7)$ & Nedd4-2 $2^{K s p 1.3}(n=6-7)$ & Control $(n=4-6)$ & Nedd4-2 $2^{\text {Kspl.3 }}(n=5-6)$ \\
\hline $\mathrm{K}^{+}(\mathrm{mM})$ & $3.63 \pm 0.21$ & $3.93 \pm 0.20$ & $4.50 \pm 0.26$ & $3.53 \pm 0.65$ \\
\hline $\mathrm{Cl}^{-}(\mathrm{mM})$ & $111.40 \pm 0.65$ & $110.10 \pm 0.96$ & $112.00 \pm 1.21^{* *}$ & $102.02 \pm 1.96^{* *}$ \\
\hline $\mathrm{Ca}^{2+}(\mathrm{mM})$ & $2.63 \pm 0.03$ & $2.49 \pm 0.08$ & $2.55 \pm 0.1$ & $2.61 \pm 0.05$ \\
\hline Protein $(\mathrm{g} / \mathrm{L})$ & $40.57 \pm 1.09$ & $40.86 \pm 1.86$ & $41.17 \pm 1.78$ & $45.00 \pm 0.63$ \\
\hline $\mathrm{HCO}_{3}^{-}(\mathrm{mM})$ & $18.86 \pm 1.7$ & $18.00 \pm 0.49$ & $18.17 \pm 1.66$ & $22.20 \pm 1.86$ \\
\hline Anion gap (mM) & $19.14 \pm 0.99$ & $21.71 \pm 0.64$ & $23.60 \pm 2.25$ & $24.60 \pm 2.64$ \\
\hline Albumin $(\mathrm{g} / \mathrm{L})$ & $12.86 \pm 0.26$ & $12.71 \pm 0.57$ & $12.50 \pm 0.77$ & $14.20 \pm 0.49$ \\
\hline Globulin $(\mathrm{g} / \mathrm{L})$ & $27.71 \pm 0.89$ & $28.14 \pm 1.32$ & $28.67 \pm 1.02$ & $30.60 \pm 0.68$ \\
\hline
\end{tabular}

Data presented as mean \pm SEM for number of mice $(n)$ indicated in parentheses. Significance was determined using a Mann-Whitney test for non-normally distributed data

$* * P<0.01$, comparing bold values
The renal tubule specific Nedd4-2 $2^{K s p l .3}$ mice do not present any signs of kidney pathology until P20 and have a normal lifespan. However, a model of complete knockout of Nedd4-2 is predominantly perinatal lethal, with the few surviving pups displaying some evidence of kidney pathology soon after birth (from $\sim 3$ days of age) [27]. Heterozygous Nedd4-2 mice have a normal lifespan [27]. We therefore investigated whether high dietary $\mathrm{Na}^{+}$fed to pregnant Nedd $4-2^{+/-}$mice would induce earlier onset of the disease during fetal development of Nedd4-2-/- pups (Supplementary Fig. 2a). Varied dietary $\mathrm{Na}^{+}$in pregnancy has been previously reported to affect the fetus, indicating the transfer of maternal $\mathrm{Na}^{+}$to the embryonic environment [30,31]. No evidence of kidney pathology or fibrosis was observed in Nedd4- $2^{-1-}$ fetuses just prior to birth at E18.5 after the standard or high- $\mathrm{Na}^{+}$diet (Supplementary Fig. 2b-d), indicating that a high- $\mathrm{Na}^{+}$diet during pregnancy does not induce fetal kidney damage in mice lacking Nedd4-2. Therefore, our results show that high- $\mathrm{Na}^{+}$levels exacerbate kidney damage caused by the lack of Nedd4-2, postnatally.

\section{High dietary $\mathrm{Na}^{+}$impairs kidney function in Nedd4- $2^{K s p 1.3}$ mice}

The analysis of serum from mice fed either standard or high-Na ${ }^{+}$diet for 20 days showed that levels of $\mathrm{Na}^{+}$or $\mathrm{K}^{+}$ remain unaltered (Fig. If and Table 1). Interestingly, $\mathrm{Cl}^{-}$ levels were significantly reduced in the Nedd4-2 $2^{\text {Spl. }}$ mice after a high-Na ${ }^{+}$diet, suggesting some $\mathrm{Na}^{+}$retention or fluid loss such as in AQP-2-deficient mice [32] (Table 1). Due to the small size of the animals, metabolic studies to measure urine volume and glomerular filtration rate were not feasible in these mice. Importantly, despite other parameters remaining similar, creatinine and urea levels were significantly increased in Nedd4-2 $2^{K s p 1.3}$ mice after the high$\mathrm{Na}^{+}$diet, suggesting that kidney function is compromised (Fig. 1f and Table 1).

\section{Low dietary $\mathrm{Na}^{+}$ameliorates kidney injury in Nedd4- $2^{K s p 1.3}$ mice}

We next assessed whether a low $\mathrm{Na}^{+}(0.05 \%)$ diet could ameliorate or reduce kidney damage (Fig. 2a). As described previously, areas of kidney damage were obvious in Nedd4$2^{\text {Ksp 1.3 }}$ kidneys on a standard $\mathrm{Na}^{+}$diet at P40 [4], however after a low $\mathrm{Na}^{+}$diet no kidney damage was apparent (Fig. 2b). Following the low $\mathrm{Na}^{+}$feeding there was a reduction in fibrosis in Nedd4-2 $2^{K s p 1.3}$ kidneys compared with the standard $\mathrm{Na}^{+}$diet, as demonstrated by picrosirius red staining for collagen (Fig. 2c). Furthermore, KIM-1 staining revealed a reduction in regions of kidney injury when compared with the standard $\mathrm{Na}^{+}$diet (Fig. 2d). Collagen, vimentin, and KIM-1 mRNA levels were all significantly increased in Nedd4-2 $2^{K s p 1.3}$ mice compared with controls on a standard $\mathrm{Na}^{+}$diet (Fig. 2e). After the low $\mathrm{Na}^{+}$ diet, levels of vimentin and KIM-1 were significantly reduced in the Nedd4-2 $2^{K s p 1.3}$ kidneys. In addition, vimentin levels were now comparable to control animals on the low $\mathrm{Na}^{+}$diet. Together these data indicate that a low $\mathrm{Na}^{+}$diet ameliorates kidney pathology in Nedd4 $-2^{K s p l .3}$ mice.

\section{Low dietary $\mathrm{Na}^{+}$alters blood parameters in Nedd4- $2^{K s p 1.3}$ mice}

The analysis of plasma electrolytes revealed no changes between control and Nedd4-2 $2^{K s p l .3}$ animals on a standard $\mathrm{Na}^{+}$diet at P40 (Fig. 2f and Table 2). In addition, electrolyte levels were not altered by the low $\mathrm{Na}^{+}$diet in either group, however urea was decreased in both control and Nedd4-2 ${ }^{K s p 1.3}$ animals (Fig. 2f). There was also a significant increase in aldosterone levels in Nedd4-2 $2^{K s p l .3}$ animals in response to the low $\mathrm{Na}^{+}$diet, suggesting an imbalance in the hormonal control of electrolytes. Furthermore, there was a trend toward increased total protein, anion gap and globulin levels in the Nedd4-2 ${ }^{K s p 1.3}$ animals, which were all 
Fig. 2 Low dietary-Na ameliorates kidney pathology in Nedd4-2 ${ }^{K s p 1.3}$ mice. a Outline of salt-feeding experiments. b Representative H\&E images show decreased injury in Nedd4 $2^{\text {Kspl. }}$ mice after low- $\mathrm{Na}^{+}$diet in P40 kidneys. Red lines denote areas of damage. Scale bar: $1 \mathrm{~mm}$, inset $100 \mu \mathrm{m}$.

c Picrosirius red staining shows a decrease in fibrosis after the low- $\mathrm{Na}^{+}$diet. Scale bar: $100 \mu \mathrm{m}$. d KIM-1 staining reveals some regions of kidney injury in Nedd4-2 $2^{K s p l .3}$ kidneys under standard- $\mathrm{Na}^{+}$diet, but no detectable regions after low- $\mathrm{Na}^{+}$ diet. Scale bar: $250 \mu \mathrm{m}$. e qPCR for markers of kidney injury, vimentin and KIM- 1 show a significant reduction in Nedd4$2^{\text {Ksp1.3 }}$ kidneys after the low-Na ${ }^{+}$ diet. Vimentin levels are comparable to control kidneys on a low- $\mathrm{Na}^{+}$diet $(n=6-7$ mice per genotype). Data are shown as fold change from control on standard (Std.) diet, mean \pm SEM with significance calculated by a Student's $t$ test (two tailed). f Serum levels of $\mathrm{Na}^{+}$remain unchanged, however, the low- $\mathrm{Na}^{+}$diet causes a decrease in urea in both control and Nedd4-2 $2^{\text {Kspl.3 }}$ mice. Aldosterone is increased in the Nedd4-2 ${ }^{K s p 1.3}$ mice after the low$\mathrm{Na}^{+}$diet. Data are presented as one point per mouse, mean \pm SEM with significance calculated by a Mann-Whitney test. $* P<0.05, * * P<0.01$, $* P<0.005$.

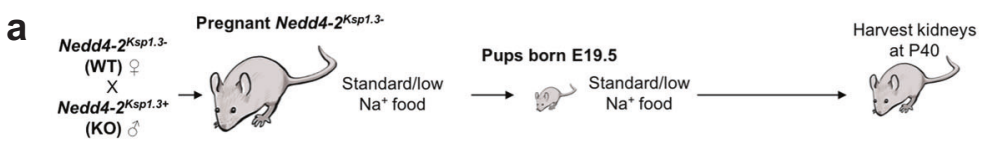

b

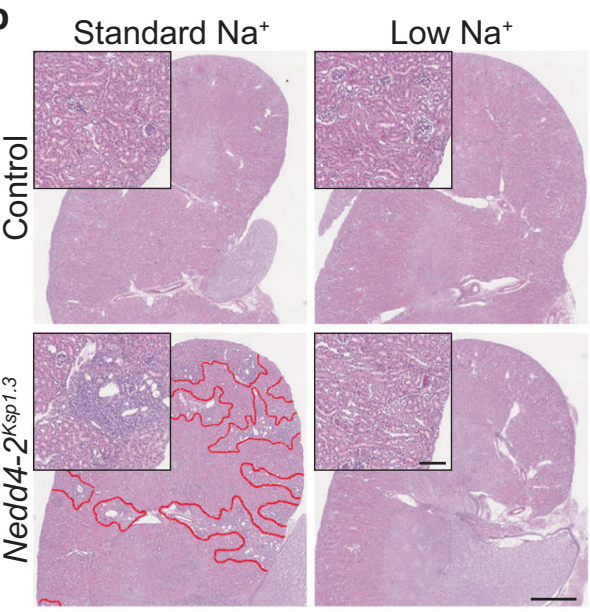

C Standard $\mathrm{Na}^{+}$
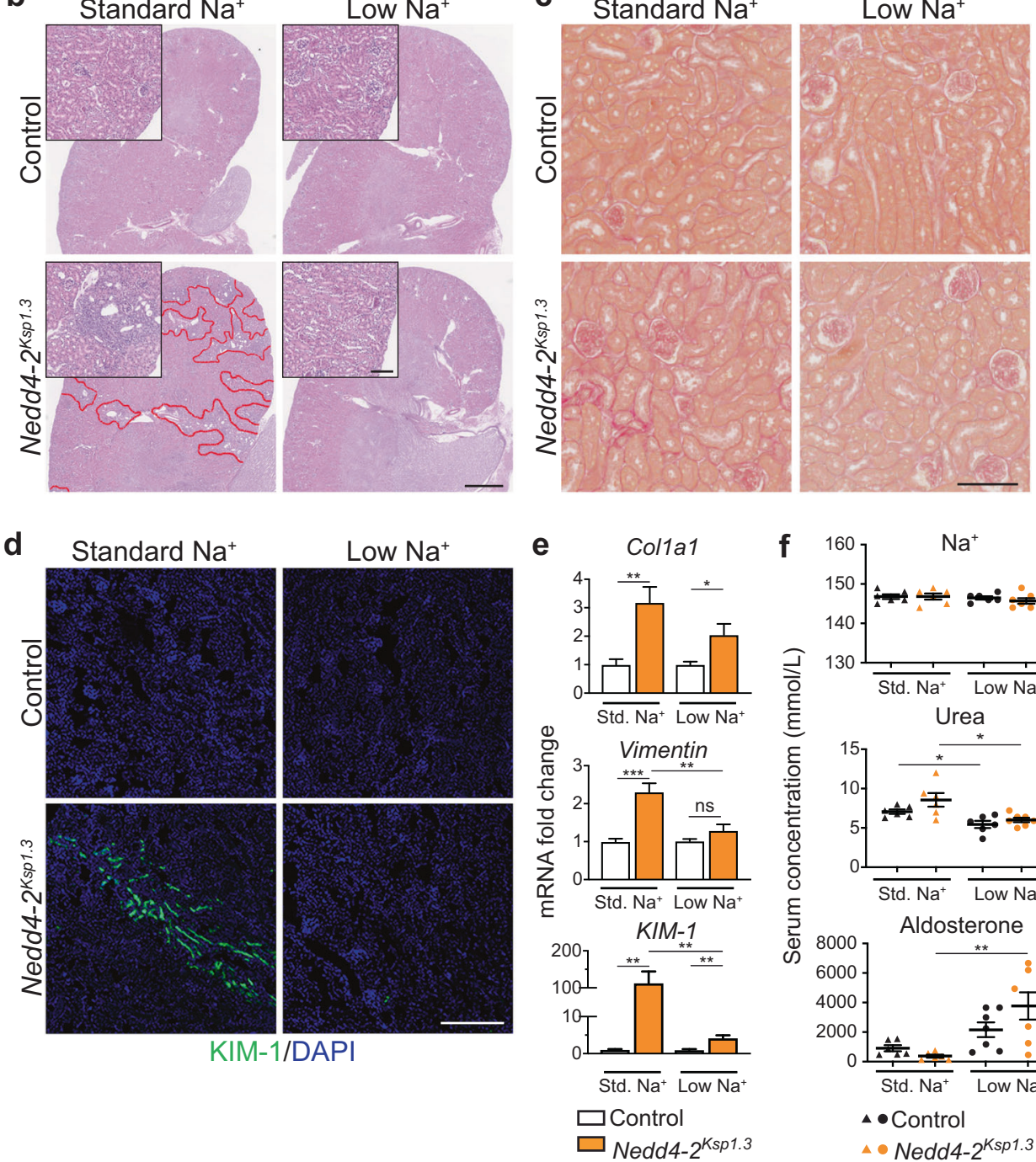

KIM-1/DAPI

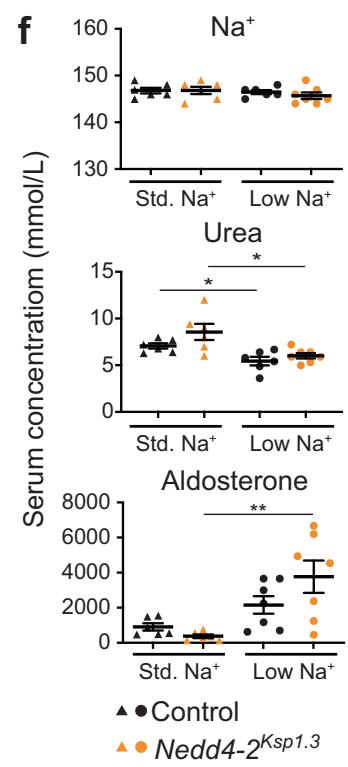

significantly reduced after the low $\mathrm{Na}^{+}$diet, indicating some improvement of kidney function (Table 2).

\section{$\mathrm{ENaC}$ levels are altered in response to high dietary $\mathrm{Na}^{+}$}

Nedd4-2 is well-known to regulate ENaC [25], but the effect of dietary $\mathrm{Na}^{+}$intake on this regulation and its contribution to the salt-sensitivity of disease has not been characterized. Hence, we sought to analyze $\mathrm{ENaC}$ levels in response to dietary $\mathrm{Na}^{+}$in control and Nedd4-2-deficient mice. Full length $\mathrm{ENaC}$ undergoes processing into active forms; present as cleaved products for $\alpha-\mathrm{ENaC}$ of $\sim 30 \mathrm{kDa}$ and $\gamma$-ENaC predominantly as $\sim 70 \mathrm{kDa}[12,33-35]$. The mature form of $\beta-\mathrm{ENaC}$ is evident as a band with slower mobility by immunoblot due to glycan remodeling [10]. At P20, Nedd4 $-2^{K s p 1.3}$ mice showed a significant increase in the mature forms of all $\mathrm{ENaC}$ subunits when compared with control mice (Fig. 3a and quantitated in Fig. 3b). The presence of a band at $\sim 65 \mathrm{kDa}$ for $\alpha$-ENaC may represent an alternative cleavage product or a nonspecific band detected by this antibody. In response to the high- $\mathrm{Na}^{+}$diet, control animals showed a significant decrease in cleaved mature $\alpha$ $\mathrm{ENaC}$ levels, and a trend toward decreased mature $\beta$ and $\gamma$-ENaC (Fig. 3b). Mature forms of $\alpha$ and $\gamma$-ENaC were significantly decreased in Nedd4-2 $2^{K s p 1.3}$ kidneys after the high- $\mathrm{Na}^{+}$diet. Importantly, these levels still remained higher than control animals. These mature forms of $\mathrm{ENaC}$ are predominantly localized at the cell membrane to form the active channel [36]. Immunostaining of membrane 
Table 2 P40 serum analysis of Control and Nedd4-2 $2^{K s p 1.3}$ mice.

Fig. 3 Downregulation of ENaC levels after high- $\mathrm{Na}^{+}$ diet is compromised in Nedd4$2^{\text {Ksp1.3 }}$ kidneys. a Semiquantitative immunoblot analysis reveals decreased expression of mature $\mathrm{ENaC}$ in control and Nedd4-2 $2^{K s p l .3}$ $\left(N 42^{K s p 1.3}\right)$ kidneys after a high$\mathrm{Na}^{+}$diet, however, levels remain elevated in Nedd4-2 $2^{K s p 1.3}$ kidneys. Expression levels quantitated in $\mathbf{b}$ as fold change from control standard diet, relative to $\beta$-actin expression. c Immunohistochemical staining of $\mathrm{ENaC}$ subunits reveals increased membrane localisation in Nedd4-2 $2^{K s p 1.3}$ kidneys. High $\mathrm{Na}^{+}$results in reduced membrane $\alpha$-ENaC in control kidneys, but not in Nedd4-2 $2^{K s p 1.3}$ kidneys. Scale bar: $50 \mu \mathrm{m} . n=$ 3 , mean \pm SEM with significance calculated by a Student's t test (2 tailed). $* P<0.05, * * * P<0.005$.

\begin{tabular}{|c|c|c|c|c|}
\hline & \multicolumn{2}{|l|}{ Standard $\mathrm{Na}^{+}$} & \multicolumn{2}{|l|}{ Low $\mathrm{Na}^{+}$} \\
\hline & Control $(n=6)$ & Nedd4-2 $2^{K s p 1.3}(n=5-6)$ & Control $(n=6-7)$ & Nedd $4-2^{K s p l .3}(n=7)$ \\
\hline $\mathrm{K}^{+}(\mathrm{mM})$ & $4.17 \pm 0.22$ & $4.10 \pm 0.20$ & $4.23 \pm 0.13$ & $4.37 \pm 0.22$ \\
\hline $\mathrm{Cl}^{-}(\mathrm{mM})$ & $109.50 \pm 0.22$ & $108.30 \pm 1.02$ & $110.00 \pm 0.68$ & $110.00 \pm 0.38$ \\
\hline $\mathrm{Ca}^{2+}(\mathrm{mM})$ & $2.46 \pm 0.04$ & $2.46 \pm 0.04$ & $2.45 \pm 0.03$ & $2.37 \pm 0.04$ \\
\hline Creatinine (uM) & $17.17 \pm 0.65$ & $18.67 \pm 1.23$ & $16.29 \pm 1.55$ & $15.43 \pm 1.13$ \\
\hline Protein $(\mathrm{g} / \mathrm{L})$ & $46.67 \pm 0.49$ & $48.00 \pm 0.58^{* *}$ & $45.17 \pm 1.22$ & $44.86 \pm 0.34^{* *}$ \\
\hline $\mathrm{HCO}_{3}^{-}(\mathrm{mM})$ & $21.00 \pm 0.73$ & $19.67 \pm 0.88$ & $21.67 \pm 0.76$ & $21.57 \pm 0.75$ \\
\hline Anion gap (mM) & $20.33 \pm 0.71$ & $23.20 \pm 0.73^{*}$ & $19.17 \pm 1.30$ & $18.43 \pm 1.13^{*}$ \\
\hline Albumin (g/L) & $14.83 \pm 0.31$ & $15.00 \pm 0.37$ & $14.17 \pm 0.48$ & $13.86 \pm 0.34$ \\
\hline Globulin (g/L) & $31.83 \pm 0.48$ & $33.00 \pm 0.58^{*}$ & $31.00 \pm 0.97$ & $31.00 \pm 0.31^{*}$ \\
\hline
\end{tabular}

Data presented as mean \pm SEM for number of mice $(n)$ indicated in parentheses. Significance was determined using a Mann-Whitney test for non-normally distributed data

$* P<0.05, * * P<0.01$, comparing values in bold
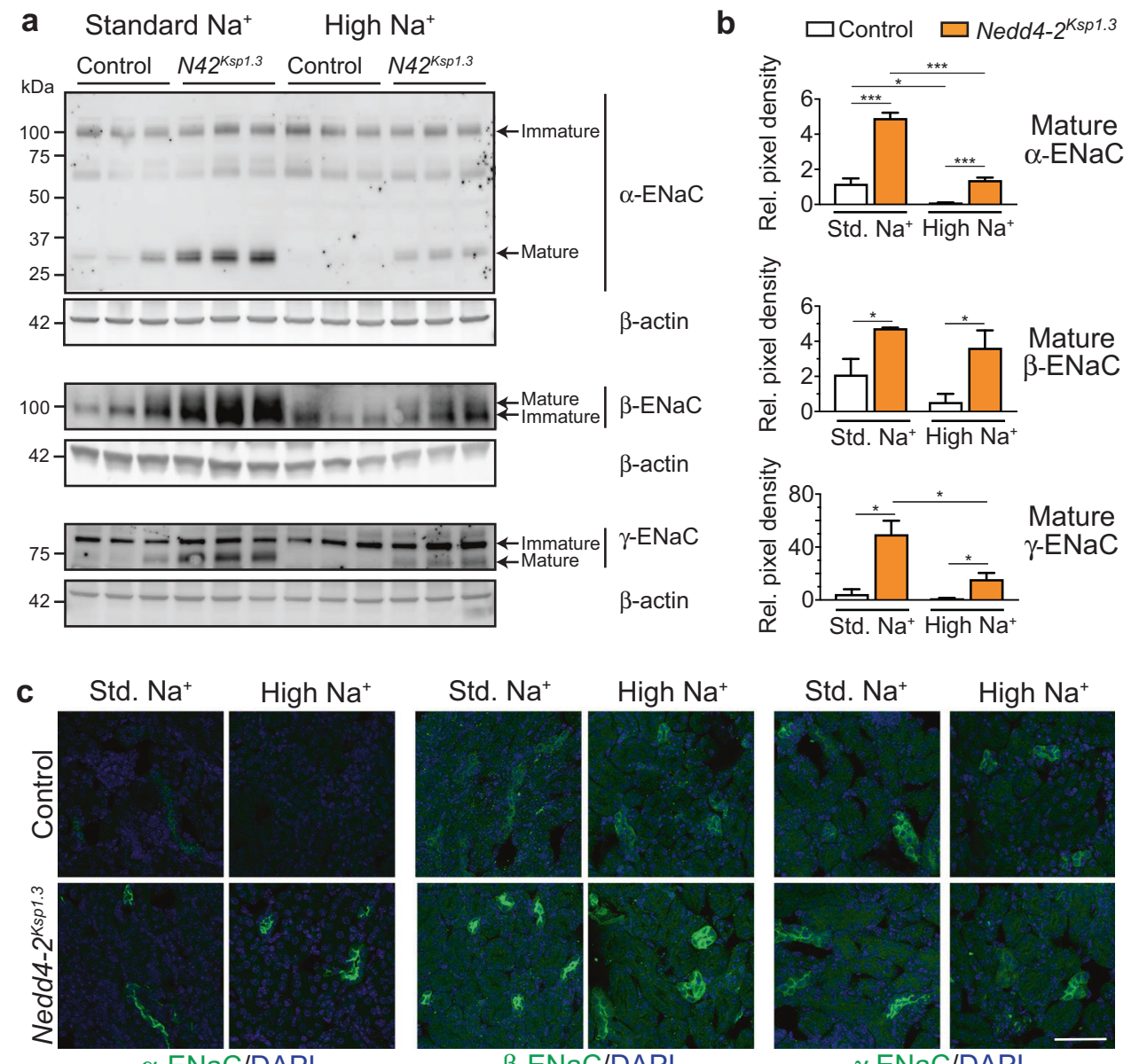

$\beta-E N a C / D A P I$ localized $\mathrm{ENaC}$ subunits confirmed the increased expression of ENaC in Nedd4-2 ${ }^{K s p 1.3}$ kidneys under a standard $\mathrm{Na}$ ${ }^{+}$diet (Fig. 3c). After the high-Na ${ }^{+}$diet, a decrease in the $\alpha$ subunit was observed in control animals, however membrane levels of all three subunits remained high in Nedd4$2^{K s p 1.3}$ kidneys. This correlated with an increase in Nedd4-2 protein expression (Supplementary Fig. 3a and b), similar to that in a previous study where dietary salt was reported to modulate Nedd4-2 [37].

At the fetal level, Nedd4-2 $2^{-/-}$kidneys displayed increased levels of the mature forms of all three $\mathrm{ENaC}$ subunits when mothers were fed a standard, low or high- $\mathrm{Na}^{+}$diet during 
Fig. $4 \mathrm{ENaC}$ levels are increased in response to low dietary $\mathrm{Na}^{+}$. a Semiquantitative immunoblot analysis reveals an increased expression of mature $\mathrm{ENaC}$ subunits in Nedd4-2 $2^{\text {spl } 1.3}$ $\left(N 42^{\text {Kspl.3 }}\right)$ kidneys. A low- $\mathrm{Na}^{+}$ diet causes an increase in $\alpha$ and $\gamma$-ENaC in Nedd4-2 $2^{K s p 1.3}$

kidneys only. Expression levels quantitated in $\mathbf{b}$ as fold change from control standard diet, relative to $\beta$-actin expression. c Immunohistochemical staining of $\mathrm{ENaC}$ subunits reveals increased membrane localization of all subunits in Nedd4-2 $2^{\text {Ksp } 1.3}$ kidneys. Low dietary $\mathrm{Na}^{+}$ results in the upregulation of membrane staining of all three $\mathrm{ENaC}$ subunits in control and Nedd4-2 ${ }^{K s p l .3}$ kidneys. Scale bar: $50 \mu \mathrm{m} . n=3$, mean \pm SEM with significance calculated by a Student's $t$ test ( 2 tailed). $* P<0.05, * * * P<0.01$, $* * * P<0.005$.

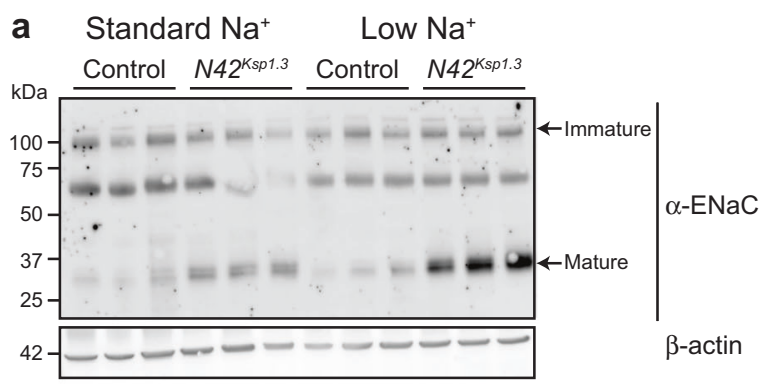

b
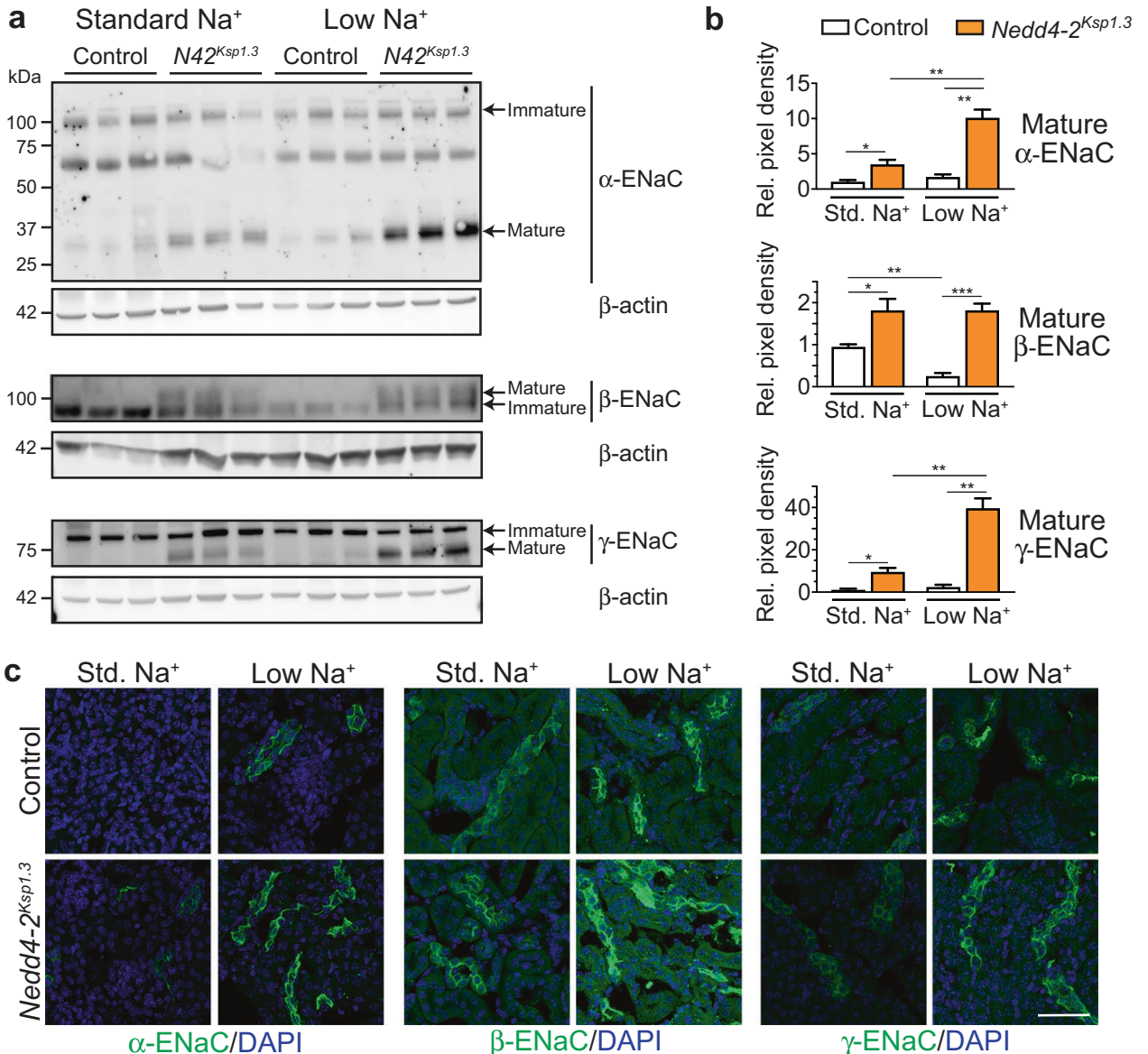

pregnancy (Supplementary Fig. 4a and b), confirming that Nedd4-2 can regulate ENaC in utero. However, compared with the standard $\mathrm{Na}^{+}$diet fed groups, both control and Nedd4-2 $2^{-/-}$animals did not show changes in the expression of any of the mature forms or membrane localized $\mathrm{ENaC}$ after a high-Na ${ }^{+}$diet (Supplementary Fig. 4). Therefore, the loss of Nedd4-2 postnatally impeded the ability to reduce $\mathrm{ENaC}$ levels in response to a high- $\mathrm{Na}^{+}$diet.

\section{ENaC levels are increased in response to low dietary $\mathrm{Na}^{+}$}

We next assessed whether low dietary $\mathrm{Na}^{+}$was affecting ENaC levels in Nedd4-2 ${ }^{K s p 1.3}$ mice at P40, when nephropathy becomes more advanced. In control animals, levels of the mature cleaved forms of $\alpha$ and $\gamma$-ENaC remained similar after a standard or low $\mathrm{Na}^{+}$diet and mature $\beta$-ENaC was expressed at very low levels (Fig. 4a and quantitated in Fig. 4b). However, in the Nedd4 $-2^{K s p 1.3}$ mice, $\alpha$ and $\gamma$ $\mathrm{ENaC}$ were significantly increased after the low $\mathrm{Na}^{+}$diet. Immunostaining of kidney sections indicated higher levels of all three subunits of ENaC localized on the membrane of tubules in Nedd4-2 $2^{K s p 1.3}$ mice compared with controls
(Fig. 4c). Low $\mathrm{Na}^{+}$diet increased $\mathrm{ENaC}$ abundance in both control and Nedd4-2 ${ }^{K s p 1.3}$ mice, without affecting Nedd4-2 levels (Fig. 4c and Supplementary Fig. 3c and d).

In fetal kidneys, low $\mathrm{Na}^{+}$caused a significant increase in cleaved mature $\gamma$-ENaC products in both control and Nedd4-2 $2^{-/-}$animals, although an increase in membrane localized $\mathrm{ENaC}$ subunits was not apparent (Supplementary Fig. 4). These results demonstrate that a low $\mathrm{Na}^{+}$diet postnatally increases mature $\mathrm{ENaC}$ expression, augmenting the amount of $\mathrm{Na}^{+}$that can be reabsorbed by the kidneys.

\section{NCC is regulated by dietary $\mathrm{Na}^{+}$in control and Nedd4-2 ${ }^{K s p 1.3}$ mice}

In addition to $\mathrm{ENaC}, \mathrm{NCC}$ also mediates $\mathrm{Na}^{+}$reabsorption in the distal convoluted tubule and has been shown to be regulated by Nedd4-2 [4, 38]. In support of this, Nedd4$2^{K s p l .3}$ mice in our study showed increased NCC at P20. Following the high-Na ${ }^{+}$diet, both control and Nedd4-2 $2^{K s p 1.3}$ kidneys downregulated total NCC to a similar extent (Fig. 5a, b). Furthermore, the membrane localization of NCC was decreased in both genotypes (Fig. 5c), suggesting that NCC is unlikely to be responsible for the high- $\mathrm{Na}^{+}$ 
Fig. 5 Changes in NCC levels in response to varied $\mathrm{Na}^{+}$diet. a Semi-quantitative immunoblot analysis of P20 kidneys shows higher expression of NCC in Nedd4-2 $2^{K s p 1.3}\left(N 42^{K s p 1.3}\right)$ kidneys under standard- $\mathrm{Na}^{+}$diets, downregulated in both control and Nedd4-2 $2^{K s p l .3}$ kidneys after high- $\mathrm{Na}^{+}$diet. Expression levels quantitated in $\mathbf{b}$ as fold change from control standard diet, relative to $\beta$-actin expression. c NCC has higher membrane expression in Nedd4-2 $2^{K s p 1.3}$ kidneys at P20 on standard- $\mathrm{Na}^{+}$ diet, downregulated to a similar level in control and Nedd4-2 $2^{\text {Ksp } 1.3}$ kidneys after high- $\mathrm{Na}^{+}$diet. d Semi-quantitative immunoblot analysis of P40 kidneys shows higher expression of NCC in Nedd4-2 $2^{\text {Kspl.3 }}$ kidneys under standard- $\mathrm{Na}^{+}$diet, upregulated in control and Nedd4-2 $2^{K s p l .3}$ kidneys after low- $\mathrm{Na}^{+}$diet. Expression levels quantitated in $\mathbf{e}$ as fold change from control standard diet, relative to $\beta$-actin expression. f Higher membrane expression of NCC in Nedd4$2^{\text {Ksp } 1.3}$ kidneys at $\mathrm{P} 40$ on standard- $\mathrm{Na}^{+}$diet, upregulated to a similar level in control and Nedd4-2 $2^{K s p 1.3}$ kidneys after low$\mathrm{Na}^{+}$diet. For graphs, $n=3$, mean \pm SEM with significance calculated by a Student's t test (2 tailed). $* P<0.05, * * P<0.01$, $* * * P<0.005$. Scale bar: $50 \mu \mathrm{m}$. a

P20

b

NCC (P20)

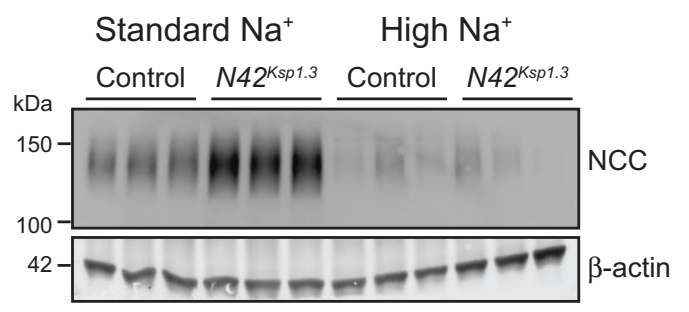

$\square$ Control $\square$ Nedd4-2 ${ }^{K s p 1.3}$

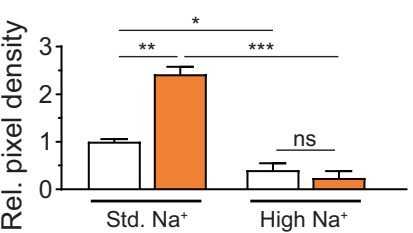

C

Control

Nedd4-2Ksp1.3
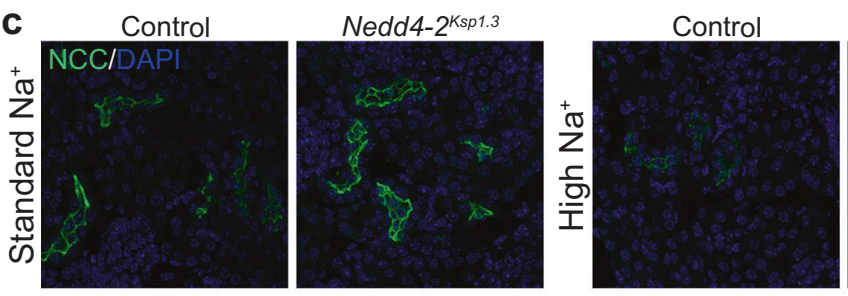

Nedd4-2 ${ }^{K s p 1.3}$

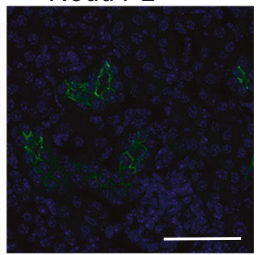

d

P40

e

NCC (P40)
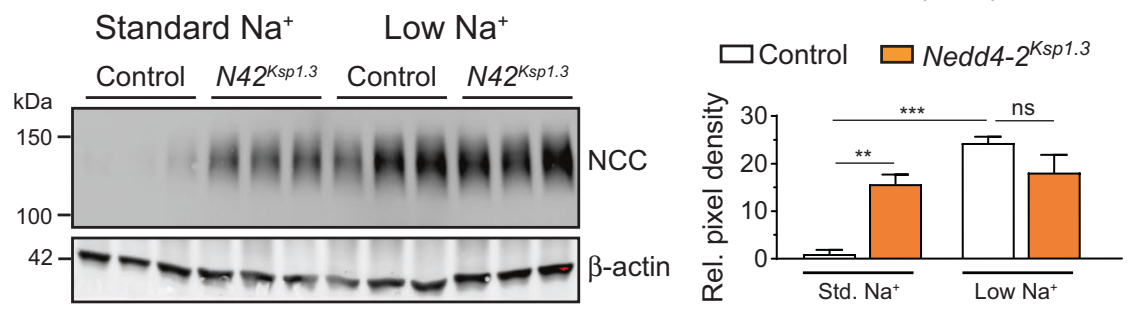

f

Control

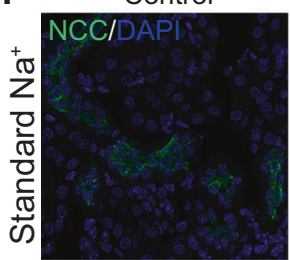

Nedd4-2 ${ }^{K s p 1.3}$
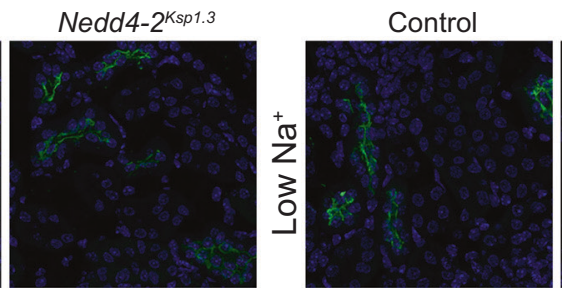

Nedd4-2Ksp1.3

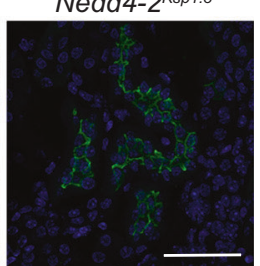

exacerbated kidney damage. At P40, Nedd4-2 $2^{\text {Ksp } 1.3}$ mice again had higher expression of total NCC (Fig. 5d and e) and membrane localized NCC (Fig. 5f). A low $\mathrm{Na}^{+}$diet resulted in a significant increase in total and membrane localized NCC in control kidneys such that no difference was observed between the genotypes after this diet (Fig. 5d-f). Together, results from this study suggest that $\mathrm{ENaC}$ is the primary contributor to the salt-sensitivity of kidney disease in Nedd4-2 $2^{K s p 1.3}$ mice.

\section{Discussion}

Nedd4-2 deficiency leads to a progressive nephropathy that is associated with increased levels of functional membrane associated $\mathrm{ENaC}$ [4]. We now demonstrate that nephropathy in Nedd4-2 $2^{K s p 1.3}$ mice is highly dependent on dietary salt, as kidney pathology is exacerbated by high- $\mathrm{Na}^{+}$and ameliorated by low $\mathrm{Na}^{+}$. Our data support that this is largely driven by increased $\mathrm{ENaC}$ in these mice, as another $\mathrm{Na}^{+}$ transporter ubiquitinated by Nedd4-2, NCC [39], is still downregulated in Nedd4-2 ${ }^{K s p 1.3}$ mice in response to high $\mathrm{Na}^{+}$. Further, the presence of renal dysplasia at later stages postnatally suggests that Nedd4-2 is likely to be required for normal nephron development after birth, as well as for protection against high- $\mathrm{Na}^{+}$induced renal damage.

High salt intake and the corresponding changes in $\mathrm{Na}^{+}$ and $\mathrm{K}^{+}$transport are known to cause renal damage [40-42]. Previous studies have demonstrated that varied dietary salt fed in pregnancy is able to pass through to embryos and offspring [30, 31]. We found that a high- $\mathrm{Na}^{+}$diet fed to pregnant Nedd4-2 $2^{+/-}$mice did not cause any apparent kidney pathology in Nedd4-2 $2^{-1-}$ fetuses by E18.5, suggesting that Nedd4-2 $2^{-/-}$mice can maintain sodium homeostasis during embryonic development. This diet fed to pregnant renal tubule specific Nedd4-2 ${ }^{K s p 1.3}$ mice and 
continued during lactation led to renal dysplasia and exacerbated kidney injury by P20, indicating that the kidney disease is salt-sensitive during postnatal stages. The specific contribution of high dietary $\mathrm{Na}^{+}$in pregnancy, lactation, the solid food of pups or a combination of these stages, remains to be explored. In contrast, a low $\mathrm{Na}^{+}$diet suppressed the development of the disease, such that renal injury was barely detectable by P40. Elevated $\mathrm{Na}^{+}$intake can lead to hypertension, resulting in subsequent renal damage [42, 43]. High dietary $\mathrm{Na}^{+}$has also been reported to induce tubular injury in the absence of elevated blood pressure, particularly in rats $[42,44]$. As we were unable to measure blood pressure in this study due to the small size of mice at P20 and P40, further studies are required to determine the contribution of hypertension, if any, to the salt-sensitivity of kidney disease in Nedd4-2 $2^{\text {Kspl.3 }}$ mice.

Mature forms of all three $\mathrm{ENaC}$ subunits were increased in fetuses and young mice lacking Nedd4-2. High- $\mathrm{Na}^{+}$diet fed to pregnant mothers did not affect $\mathrm{ENaC}$ levels in either wildtype or $\mathrm{Nedd4}-2^{-/-}$fetuses. Postnatally, a high- $\mathrm{Na}^{+}$diet resulted in lower levels of $\alpha$-ENaC in wild-type mice, correlating with the increased Nedd4-2 levels, in support of a previous study where Nedd4-2 levels were shown to be regulated by dietary $\mathrm{Na}^{+}$[37]. Nedd4-2-deficient mice, which have elevated membrane associated $\mathrm{ENaC}$ subunits on a standard laboratory diet, failed to efficiently downregulate $\alpha$ $\mathrm{ENaC}$ after the high- $\mathrm{Na}^{+}$feeding, similar to Dahl saltsensitive rats [45]. We propose that the high levels of $\mathrm{ENaC}$ aid in the reabsorption of elevated $\mathrm{Na}^{+}$which in turn exacerbates kidney damage in Nedd4-2 $2^{K s p 1.3}$ mice. Hypertonicity caused by high $\mathrm{NaCl}$ concentrations is known to alter cellular responses [46]. Various mechanisms have been proposed to explain how high $\mathrm{Na}^{+}$induces renal tubular damage, such as via apoptosis, glomerular hyperfiltration, activation of the renin-angiotensin-aldosterone system, oxidative stress and proteinuria [42, 47]. Understanding the direct contribution of elevated $\mathrm{ENaC}$ to the damaged renal parenchyma caused by high dietary $\mathrm{Na}^{+}$remains to be established.

Conversely, a low $\mathrm{Na}^{+}$diet increased membrane localized mature $\mathrm{ENaC}$ expression. Despite this, kidney pathology was ameliorated in Nedd4- $2^{K s p l .3}$ mice fed on this diet. Hence, we hypothesize that despite high $\mathrm{ENaC}$ levels, the low amount of $\mathrm{Na}^{+}$in the diet is sufficient to limit disease progression.

Increased expression and membrane localization of $\mathrm{ENaC}$ subunits has been observed in other models of Nedd4-2 deficiency, contributing to the observed phenotypes [4, 21, 25, 27, 48, 49]. A model of inducible renalspecific Nedd4-2 knockout in proximal and distal tubules, and collecting ducts $\left(\mathrm{Ned} d 4 \mathrm{~L}^{\mathrm{Pax} 8 / \mathrm{LCl}}\right.$ ) revealed a hypertensive phenotype only after a high- $\mathrm{Na}^{+}$diet, attributed to the increased levels of NCC [38]. Interestingly, in our study NCC levels were downregulated to a similar level in both wild-type and Nedd4-2 $2^{K s p 1.3}$ kidneys, suggesting that this is unlikely to be responsible for the salt-sensitivity of nephropathy. Nedd $4 L^{\text {Pax } 8 / L C l}$ mice displayed increased $\beta$ and $\gamma$-ENaC after a high- $\mathrm{Na}^{+}$diet when compared with control mice. The absence of kidney injury in these mice may be explained by a lack of increased mature $\alpha-\mathrm{ENaC}$ or the specific location or timing of Nedd4-2 knockout in this inducible system [25].

Nedd4-2 (NEDD4L) variants and single nucleotide polymorphisms (SNPs) are known to be associated with human hypertension [50] and end-stage renal disease due to autosomal dominant polycystic kidney disease and juvenile nephronopthisis [51]. The effect of these SNPs on ENaC levels in these patients has not been investigated. NEDD4L variants in patients with CKD-like pathologies have not yet been characterized, however decreased expression of $N E D D 4 L$ has recently been observed in early diabetic nephropathy [5]. This supports our findings that loss of $N E D D 4 L$ may contribute to the development of nephropathy, with the potential for its expression levels to be utilized as a biomarker for early stage disease. It has been reported that short term salt reduction in people with CKD reduced blood pressure and proteinuria [52], however the effects of $\mathrm{Na}^{+}$ restriction on primary endpoints and progression to end-stage renal disease have not been assessed. Findings in this study warrant future endeavors into providing robust clinical evidence for a need to restrict dietary $\mathrm{Na}^{+}$in patients with potential susceptibility to kidney disease.

Acknowledgements We are grateful to Johannes Loffing for $\alpha$ and $\gamma$ ENaC antibodies. This work was supported by a National Health and Medical Research Council (NHMRC) of Australia Senior Principal Research Fellowship (GNT1103006) and project grant (GNT1099307) to SK as well as a Biomed City Project Grant from The Hospital Research Foundation (THRF) to SK, JAM, and JF.

\section{Compliance with ethical standards}

Conflict of interest The authors declare that they have no conflict of interest.

Publisher's note Springer Nature remains neutral with regard to jurisdictional claims in published maps and institutional affiliations.

Open Access This article is licensed under a Creative Commons Attribution 4.0 International License, which permits use, sharing, adaptation, distribution and reproduction in any medium or format, as long as you give appropriate credit to the original author(s) and the source, provide a link to the Creative Commons license, and indicate if changes were made. The images or other third party material in this article are included in the article's Creative Commons license, unless indicated otherwise in a credit line to the material. If material is not included in the article's Creative Commons license and your intended use is not permitted by statutory regulation or exceeds the permitted use, you will need to obtain permission directly from the copyright holder. To view a copy of this license, visit http://creativecommons. org/licenses/by/4.0/. 


\section{References}

1. Rysz J, Gluba-Brzozka A, Franczyk B, Jablonowski Z, Cialkowska-Rysz A. Novel biomarkers in the diagnosis of chronic kidney disease and the prediction of its outcome. Int J Mol Sci. 2017;18:1702-18.

2. Humphreys BD. Mechanisms of renal fibrosis. Annu Rev Physiol. 2018;80:309-26.

3. Vivante A, Hildebrandt F. Exploring the genetic basis of earlyonset chronic kidney disease. Nat Rev Nephrol. 2016;12:133-46.

4. Henshall TL, Manning JA, Alfassy OS, Goel P, Boase NA, Kawabe $\mathrm{H}$, et al. Deletion of Nedd4-2 results in progressive kidney disease in mice. Cell Death Differ. 2017;24:2150-60.

5. Wilson PC, Wu H, Kirita Y, Uchimura K, Ledru N, Rennke HG, et al. The single-cell transcriptomic landscape of early human diabetic nephropathy. Proc Natl Acad Sci USA. 2019;116: 19619-25.

6. Boero R, Pignataro A, Quarello F. Salt intake and kidney disease. J Nephrol. 2002;15:225-9.

7. Greger R. Physiology of renal sodium transport. Am J Med Sci. 2000;319:51-62.

8. Butterworth MB. Regulation of the epithelial sodium channel $(\mathrm{ENaC})$ by membrane trafficking. Biochim Biophys Acta. 2010;1802:1166-77.

9. Stewart AP, Haerteis S, Diakov A, Korbmacher C, Edwardson JM. Atomic force microscopy reveals the architecture of the epithelial sodium channel (ENaC). J Biol Chem. 2011;286:31944-52.

10. Kashlan OB, Kinlough CL, Myerburg MM, Shi S, Chen J, Blobner BM, et al. N-linked glycans are required on epithelial $\mathrm{Na}$ $(+)$ channel subunits for maturation and surface expression. Am J Physiol Ren Physiol. 2018;314:F483-F92.

11. Kleyman TR, Carattino MD, Hughey RP. ENaC at the cutting edge: regulation of epithelial sodium channels by proteases. J Biol Chem. 2009;284:20447-51.

12. Ray EC, Kleyman TR. Cutting it out: $\mathrm{ENaC}$ processing in the human nephron. J Am Soc Nephrol. 2015;26:1-3.

13. Kleyman TR, Kashlan OB, Hughey RP. Epithelial $\mathrm{Na}(+)$ channel regulation by extracellular and intracellular factors. Annu Rev Physiol. 2018;80:263-81.

14. Pavlov TS, Staruschenko A. Involvement of ENaC in the development of salt-sensitive hypertension. Am J Physiol Ren Physiol. 2017;313:F135-F40.

15. Masilamani S, Kim GH, Mitchell C, Wade JB, Knepper MA. Aldosterone-mediated regulation of $\mathrm{ENaC}$ alpha, beta, and gamma subunit proteins in rat kidney. J Clin Invest. 1999;104: R19-23.

16. Udwan K, Abed A, Roth I, Dizin E, Maillard M, Bettoni C, et al. Dietary sodium induces a redistribution of the tubular metabolic workload. J Physiol. 2017;595:6905-22.

17. Frindt G, Ergonul Z, Palmer LG. Na channel expression and activity in the medullary collecting duct of rat kidney. Am J Physiol Ren Physiol. 2007;292:F1190-6.

18. Frindt G, Masilamani S, Knepper MA, Palmer LG. Activation of epithelial $\mathrm{Na}$ channels during short-term $\mathrm{Na}$ deprivation. Am J Physiol Ren Physiol. 2001;280:F112-8.

19. Aoi W, Niisato N, Sawabe Y, Miyazaki H, Tokuda S, Nishio K, et al. Abnormal expression of ENaC and SGK1 mRNA induced by dietary sodium in Dahl salt-sensitively hypertensive rats. Cell Biol Int. 2007;31:1288-91.

20. Cui Y, Tong A, Jiang J, Wang F, Li C. Liddle syndrome: clinical and genetic profiles. J Clin Hypertens. 2017;19:524-9.

21. Shi PP, Cao XR, Sweezer EM, Kinney TS, Williams NR, Husted $\mathrm{RF}$, et al. Salt-sensitive hypertension and cardiac hypertrophy in mice deficient in the ubiquitin ligase Nedd4-2. Am J Physiol Ren Physiol. 2008;295:F462-70.
22. Fotia AB, Dinudom A, Shearwin KE, Koch JP, Korbmacher C, Cook DI, et al. The role of individual Nedd4-2 (KIAA0439) WW domains in binding and regulating epithelial sodium channels. FASEB J. 2003;17:70-2.

23. Goel P, Manning JA, Kumar S. NEDD4-2 (NEDD4L): the ubiquitin ligase for multiple membrane proteins. Gene. 2015;557:1-10.

24. Harvey KF, Dinudom A, Cook DI, Kumar S. The Nedd4-like protein KIAA0439 is a potential regulator of the epithelial sodium channel. J Biol Chem. 2001;276:8597-601.

25. Manning JA, Kumar S. Physiological functions of Nedd4-2: Lessons from knockout mouse models. Trends Biochem Sci. 2018;43:635-47.

26. Manning JA, Henshall TL, Kumar S. NEDD4-2-dependent control of $\mathrm{Na}(+)$ homeostasis and renal disease. Cell Cycle. 2018;17:1-2.

27. Boase NA, Rychkov GY, Townley SL, Dinudom A, Candi E, Voss AK, et al. Respiratory distress and perinatal lethality in Nedd4-2-deficient mice. Nat Commun. 2011;2:287.

28. Rubera I, Loffing J, Palmer LG, Frindt G, Fowler-Jaeger N, Sauter $\mathrm{D}$, et al. Collecting duct-specific gene inactivation of alphaENaC in the mouse kidney does not impair sodium and potassium balance. J Clin Invest. 2003;112:554-65.

29. Foot NJ, Gembus KM, Mackenzie K, Kumar S. Ndfip2 is a potential regulator of the iron transporter DMT1 in the liver. Sci Rep. 2016;6:24045.

30. Chou R, Hara A, Du D, Shimizu N, Sakuyama H, Uehara Y. Lowsalt intake during mating or gestation in rats Is associated with low birth and survival rates of babies. J Nutr Metab. 2014;2014:212089.

31. Mao C, Liu R, Bo L, Chen N, Li S, Xia S, et al. High-salt diets during pregnancy affected fetal and offspring renal reninangiotensin system. J Endocrinol. 2013;218:61-73.

32. Kortenoeven ML, Pedersen NB, Miller RL, Rojek A, Fenton RA. Genetic ablation of aquaporin-2 in the mouse connecting tubules results in defective renal water handling. J Physiol. 2013;591:2205-19.

33. Hughey RP, Mueller GM, Bruns JB, Kinlough CL, Poland PA, Harkleroad KL, et al. Maturation of the epithelial $\mathrm{Na}+$ channel involves proteolytic processing of the alpha- and gamma-subunits. J Biol Chem. 2003;278:37073-82.

34. Ergonul Z, Frindt G, Palmer LG. Regulation of maturation and processing of $\mathrm{ENaC}$ subunits in the rat kidney. Am J Physiol Ren Physiol. 2006;291:F683-93.

35. Yang L, Frindt G, Lang F, Kuhl D, Vallon V, Palmer LG. SGK1dependent $\mathrm{ENaC}$ processing and trafficking in mice with high dietary $\mathrm{K}$ intake and elevated aldosterone. Am J Physiol Ren Physiol. 2017;312:F65-F76.

36. Zhou R, Patel SV, Snyder PM. Nedd4-2 catalyzes ubiquitination and degradation of cell surface ENaC. J Biol Chem. 2007;282:20207-12.

37. Loffing-Cueni D, Flores SY, Sauter D, Daidie D, Siegrist N, Meneton P, et al. Dietary sodium intake regulates the ubiquitinprotein ligase nedd4-2 in the renal collecting system. J Am Soc Nephrol. 2006;17:1264-74.

38. Ronzaud C, Loffing-Cueni D, Hausel P, Debonneville A, Malsure SR, Fowler-Jaeger N, et al. Renal tubular NEDD4-2 deficiency causes NCC-mediated salt-dependent hypertension. J Clin Invest. 2013;123:657-65.

39. Arroyo JP, Lagnaz D, Ronzaud C, Vazquez N, Ko BS, Moddes L, et al. Nedd4-2 modulates renal $\mathrm{Na}^{+}-\mathrm{Cl}^{-}$cotransporter via the aldosterone-SGK1-Nedd4-2 pathway. J Am Soc Nephrol. 2011;22:1707-19.

40. Cao W, Li A, Wang L, Zhou Z, Su Z, Bin W, et al. A salt-induced reno-cerebral reflex activates renin-angiotensin systems and promotes CKD progression. J Am Soc Nephrol. 2015;26:1619-33. 
41. Pavlov TS, Levchenko V, O'Connor PM, Ilatovskaya DV, Palygin O, Mori T, et al. Deficiency of renal cortical EGF increases ENaC activity and contributes to salt-sensitive hypertension. J Am Soc Nephrol. 2013;24:1053-62.

42. Lambers Heerspink HJ, Navis G, Ritz E. Salt intake in kidney disease-a missed therapeutic opportunity? Nephrol Dial Transpl. 2012;27:3435-42.

43. Rossier BC, Staub O, Hummler E. Genetic dissection of sodium and potassium transport along the aldosterone-sensitive distal nephron: importance in the control of blood pressure and hypertension. FEBS Lett. 2013;587:1929-41.

44. Washino S, Hosohata K, Jin D, Takai S, Miyagawa T. Early urinary biomarkers of renal tubular damage by a high-salt intake independent of blood pressure in normotensive rats. Clin Exp Pharmacol Physiol. 2017;45:261-68.

45. Kakizoe Y, Kitamura K, Ko T, Wakida N, Maekawa A, Miyoshi $\mathrm{T}$, et al. Aberrant ENaC activation in Dahl salt-sensitive rats. $\mathbf{J}$ Hypertens. 2009;27:1679-89.

46. Burg MB, Ferraris JD, Dmitrieva NI. Cellular response to hyperosmotic stresses. Physiol Rev. 2007;87:1441-74.
47. Mallamaci F, Tripepi G. Salt restriction in chronic kidney disease: a simple need or a must? Kidney Blood Press Res. 2014;39:124-8.

48. Van Huysse JW, Amin MS, Yang B, Leenen FH. Salt-induced hypertension in a mouse model of Liddle syndrome is mediated by epithelial sodium channels in the brain. Hypertension. 2012;60:691-6.

49. Kimura T, Kawabe H, Jiang C, Zhang W, Xiang YY, Lu C, et al. Deletion of the ubiquitin ligase Nedd4L in lung epithelia causes cystic fibrosis-like disease. Proc Natl Acad Sci USA 2011; 108:3216-21.

50. Rizzo F, Staub O. NEDD4-2 and salt-sensitive hypertension. Curr Opin Nephrol Hypertens. 2015;24:111-6.

51. Fouladkou F, Alikhani-Koopaei R, Vogt B, Flores SY, MalbertColas L, Lecomte MC, et al. A naturally occurring human Nedd42 variant displays impaired $\mathrm{ENaC}$ regulation in Xenopus laevis oocytes. Am J Physiol Ren Physiol. 2004;287:F550-61.

52. McMahon EJ, Campbell KL, Bauer JD, Mudge DW. Altered dietary salt intake for people with chronic kidney disease. Cochrane Database Syst Rev. 2015;(2):Art.No. CD010070. 